\title{
First records of three Lepiota species (Agaricales, Basidiomycota) from Ukraine, with notes on a poorly known species, Lepiota subalba
}

\author{
Oleh PRYLUTSKYI ${ }^{1 *}$ (D), Oleksandr ZINENKO ${ }^{1,2}$ (D), Polina HAVRYSH ${ }^{1}$ \\ ${ }^{1}$ V.N. Karazin Kharkiv National University, 4 Svobody Sq., Kharkiv 61022, Ukraine \\ ${ }^{2}$ Natural History Museum, V.N. Karazin Kharkiv National University, 8 Trinkler Str., Kharkiv 61058, Ukraine
}

\begin{abstract}
New records of four species of the genus Lepiota (Agaricales, Basidiomycota) are reported from Ukraine. Three species, L. fuscovinacea, L. griseovirens, and L. roseolivida, are recorded in Ukraine for the first time, whereas a poorly known species, L. subalba, earlier known in Ukraine from a few records, is confirmed using molecular identification methods. All species reports are supplemented with original descriptions and drawings based on newly collected material, as well as data on general distribution, habitat, references to new collections and public databases. Original nucleotide sequence of the ITS region of ribosomal DNA obtained from our voucher specimen of $L$. subalba is provided.
\end{abstract}

Keywords: DNA barcoding, fungal diversity, ITS, lepiotaceous fungi, new records, Ukraine

Article history. Submitted 10 October 2021. Revised 20 December 2021. Published 31 December 2021

Citation. Prylutskyi O., Zinenko O., Havrysh P. 2021. First records of three Lepiota species (Agaricales, Basidiomycota) from Ukraine, with notes on a poorly known species Lepiota subalba. Ukrainian Botanical Journal, 78(6): 373-380. https://doi.org/10.15407/ukrbotj78.06.373

"Corresponding author (e-mail: prylutskyi@karazin.ua)

\section{Introduction}

Lepiota (Pers) S.F.Gray (Agaricaceae) is a genus that comprises ca. 400 species (Kirk et al., 2008; Vellinga, 2009). Most of them are soil and litter decomposers, which are widely distributed from tropical to temperate regions (Vellinga, 2004). Several genera, such as Cystolepiota Singer, Echinoderma (Locq. ex Bon) Bon, Melanophyllum Velen., Pulverolepiota Bon, Leucoagaricus Locq. ex Singer, Leucocoprinus Pat., and Chlorophyllum Massee, share certain common features with Lepiota s. str. and thus their species were earlier (until the early 2000s) treated as members of Lepiota s. 1. (Johnson, 1999; Vellinga, 2003, 2009). For convenience, the term "lepiotaceous fungi" has been widely used until now as an informal group that embraces the mentioned genera with colorless or differently (non-black) colored spores, in contrast to the type genus of the family, Agaricus L.
The first comprehensive list of lepiotaceous fungi of Ukraine was provided in the Handbook of Fungi of Ukraine (Zerova et al., 1979), where 33 species of Lepiota s. 1. were reported. Wasser (1980) reported 37 accepted species names of Lepiota in his revision of the order Agaricales in Ukraine. The Fungi of Ukraine online database, which summarizes historical collections of the KW-M Herbarium of the $20^{\text {th }}$ century, provides 36 species names of Lepiota (Andrianova et al., 2006). Afterwards, lepiotaceous fungi were not in focus of special studies and were investigated instead within wider research projects (Table 1).

These studies differ by their scope and geographical coverage from local and regional research (Dudka et al., 2004; Sarkina, 2013; Prylutskyi et al., 2017; Prylutskyi, 2018; Kozłowska et al., 2019; Makarenko, 2020; Malaniuk, 2020) through macro-regional surveys (Wasser, Soldatova, 1977; Dudka et al., 2009, 2019)

(C) 2021 O. Prylutskyi, O. Zinenko, P. Havrysh. Published by the M.G. Kholodny Institute of Botany, NAS of Ukraine. This is an open access article under the terms of the Creative Commons Attribution License (http://creativecommons.org/licenses/by/4.0/), which permits use, distribution, and reproduction in any medium, provided the original work is properly cited 
Table 1. General summary of recent (2000-onwards) and historical (1950-2000) studies on the genus Lepiota in Ukraine

\begin{tabular}{|c|c|c|}
\hline Publication (authors, date, shortened title) & Level & $\begin{array}{c}\text { Number of Lepiota } \\
\text { species reported }\end{array}$ \\
\hline Makarenko, 2020, Agaricales, Boletales, and Russulales of the Psel River basin (Left-Bank Forest-Steppe) & regional & 9 \\
\hline Malaniuk, 2020, Agarics and Boletes of Halych National Nature Park (West-Ukrainian and Precarpathian Forests) & local & 7 \\
\hline Dudka et al., 2019, Fungi of the Ukrainian Carpathians & $\begin{array}{l}\text { macro- } \\
\text { regional }\end{array}$ & 10 \\
\hline Prylutskyi, 2018, Agarics of Kharkiv Forest-Steppe & regional & 7 \\
\hline Sarkina, 2013, Fungi of Crimea & regional & 16 \\
\hline Dudka et al., 2009, Fungi of protected areas of Left-Bank Ukraine & $\begin{array}{l}\text { macro- } \\
\text { regional }\end{array}$ & 24 \\
\hline Andrianova et al., 2006, Fungi of Ukraine database & national & 36 \\
\hline Dudka et al., 2004, Fungi of Crimea & regional & 12 \\
\hline
\end{tabular}

to the national-level overviews (Zerova et al., 1979; Andrianova et al., 2006) and the critical revision (Wasser, 1980). Note that the older studies treated the genus sensu lato.

Here we provide original descriptions for recently collected specimens of four rare and interesting Lepiota species. Lepiota griseovirens Maire and L. roseolivida Murrill (as Leucoagaricus roseilividus (Murrill) E.Ludw.) previously have been briefly reported as the first records in Ukraine in the conference paper and $\mathrm{PhD}$ thesis (Havrysh et al., 2018; Prylutskyi, 2018), whereas Lepiota fuscovinacea F.H.Møller \& J.E.Lange is reported here for the first time for Ukraine. We also provide an original description and nrITS sequence of our specimen of the rare and poorly known species Lepiota subalba Kühner ex P.D.Orton.

\section{Materials and Methods}

Specimens and morphological descriptions. Material was collected in Kyiv (central Ukraine) and Kharkiv (northeastern Ukraine) regions by the authors. Fruit bodies were photographed and annotated in the field. Collected specimens are deposited in the Mycological herbarium of V.N. Karazin Kharkiv National University CWU(MYC).

The microscopic structures were observed in dried material. Sections of specimens were cut by hand and mounted in 5\% KOH. Dimensions were determined for basidiospores, basidia, cheilocystidia, and elements of the pileus covering based on ocular micrometer measurements for at least 20 basidiospores and at least 10 measures for other structures per specimen. Extreme values are given in parentheses. The following abbreviations are used: L number of lamellae, 1 - number of lamellulae that do not reach the stem, $\mathrm{Q}$ - length/width ratio of basidiospores. Species names follow the Index Fungorum database, except $L$. roseolivida, for which we followed Vellinga's (2009) opinion, with arguments provided in the Results and Discussion section.

DNA extraction, amplification and sequencing. DNA from dry herbarium material (part of fruiting body) was extracted using NeoPrep 100 plant (Neogene, Ukraine). Fragment of the ribosomal ITS region was amplified using standard reaction conditions and primers ITS1 and ITS4 (White et al., 1990) using OneTaq ${ }^{\circledR}$ QuickLoad ${ }^{\circledR}(2 \mathrm{X})$ Taq polymerase (New England Biolabs, M0488S). Products were visualized prior to sequencing in commercial sequencing facility (Macrogen Europe) with forward primer. Obtained chromatograms were checked by eye, low quality fragments in the beginning and the end were trimmed. Resulting sequences in fasta format were compared to the most similar sequences in open databases GenBank (Benson et al., 2013), Unite (Nilsson et al., 2019), and Mycobank (Crous et al., 2004) using available online search algorithms.

Five high-quality sequences of the nrITS region were selected as references for identification of Lepiota subalba, four isolated from specimens identified as $L$. subalba, and one - as a closely related species, L. ignicolor (Table 2).

Ukrainian Botanical Journal, 2021, 78(6) 
Table 2. Reference sequences from open databases, highly similar to our nrITS sequence of Lepiota subalba, and their voucher specimens

\begin{tabular}{|c|c|c|c|c|}
\hline Identification and origin & ITS sequence accession number & ITS sequence database & Herbarium specimen number & Identified by \\
\hline $\begin{array}{l}\text { L. subalba, } \\
\text { Estonia }\end{array}$ & UDB015447 | 118281 & UNITE & TUF118281 & Vello Liiv \\
\hline $\begin{array}{l}\text { L. subalba, } \\
\text { Norway }\end{array}$ & NOBAS2394-16 | UDB036474 & UNITE & O-F-21061 & Thomas Læssøe \\
\hline $\begin{array}{l}\text { L. subalba, } \\
\text { Norway }\end{array}$ & NOBAS1639-15 | UDB036113 & UNITE & O-F-80243 & Katriina Bendiksen \\
\hline $\begin{array}{l}\text { L. subalba, } \\
\text { the Netherlands }\end{array}$ & AY176489.1 & NCBI & $2242(\mathrm{~L})$ & Else Vellinga \\
\hline $\begin{array}{l}\text { L. ignicolor, } \\
\text { the Netherlands }\end{array}$ & AY176472.1 & NCBI & Unknown (herb. Huijser) & Henk A. Huijser \\
\hline
\end{tabular}

Evolutionary analyses were conducted in MEGA X (Kumar et al., 2018)

\section{Data accessibility}

Specimens' metadata and photos are deposited in the PlutoF database (Abarenkov et al., 2010) and accessible via their collection numbers with CWU(MYC) prefixes. The nrITS sequence of $L$. subalba is available through the GenBank, accession number OK041522.

\section{Results and Discussion}

\section{Genus Lepiota}

Lepiota fuscovinacea F.H.Møller \& J.E.Lange, Fl. Agaric. Danic. 5 (Taxon. Consp.): V (1940) - Figs 1,A, 2,A.

Pileus 3.0-4.5 $\mathrm{cm}$ diam. at first campanulate, expanding to umbonate, with wide umbo and slightly convoluted margin, pale brown-wine, gray-wine color with lilac-grayish to purple tinge, closely covered with brown to dark-purple tomentose-fibrillose squamules. Lamellae free, crowded, $\mathrm{L}=40-50,1=5-10$, white to cream, yellowish in older specimen. Stipe 3-6 $\times 0.3-$ $0.8 \mathrm{~cm}$, subcylindrical, hollow, slightly inflated at base, cream to pale wine at apical part, getting darker to base, reaching grayish-purple, brown-purple, with concolorous fugacious, fibrillose belts at annual zone and below, smooth above annual zone. Stem base with white mycelium cords. Basidiospores 4.5-5.5 × 2.0-2.5 $\mu \mathrm{m}$, $\mathrm{Q}=1.8-2.12$, oblong to subcylindrical in side view, slightly narrowed to apex, ellipsoid to ovoid in front view, slightly thick-walled, hyaline, smooth, dextrinoid, non- or slightly metachromatic. Basidia 15-20 × 5.5$6.5 \mu \mathrm{m}$, clavate, four-spored. Pleurocystidia absent. Cheilocystidia $20-35 \times(6-) 7-13 \mu \mathrm{m}$, widely clavate to narrowly spheropedunculate, hyaline in $\mathrm{KOH}$. Pileus covering a trichoderm, composed of elongate septated subcylindrical elements, (40-)60-100(-140) $\times 10$
$20 \mu \mathrm{m}$, with brownish pigment, terminate elements are slightly narrowed and rounded to apex. Clamp connections absent.

Material examined. UKRAINE. Kyiv Region, Obukhiv District, near Rzhyshchiv town, 49.960841 $\mathrm{N}, 31.118578 \mathrm{E}$, on rich soil with clay basis, deciduous forest in ravine with Betula pendula, Alnus glutinosa, Populus tremula, Tilia cordata, 16 Oct. 2020, O. Prylutskyi (CWU(MYC)8692). iNaturalist observation (https://www.inaturalist.org/observations/62769742).

Habitat and distribution. Solitary or in small groups, terrestrial on loamy or clayey soil, rich in humus, in deciduous and coniferous woods and plantations. Reported from Austria, Belgium, Denmark, Estonia, Finland, France, Germany, Italy, Norway, Poland, Slovenia, Spain, Sweden, Switzerland, the Netherlands, Ukraine, and the United Kingdom (Candusso, Lanzoni, 1990; Noordeloos et al., 2001; Lange, 2012; GBIF, 2021a). Considered as a rare species throughout its range, especially in Nordic countries (Lange, 2012).

Lepiota griseovirens Maire, Bull. trimest. Soc. mycol. Fr. 44: 37 (1928) - Figs 1,B, 2,B.

Lepiota poliochloodes Vellinga \& Huijser, Persoonia 15(2): 229 (1993).

Pileus 3-4 cm diam., at first conical, campanulate, then expanding to umbonate, almost applanate with wide umbo in center, dark greenish-gray color at first, olive, gray or brown, then disparting from margin into squamules in concentric zones laying on white background, remaining dark in center, when young with parts of veil at margin. Lamellae free, moderately crowded, $\mathrm{L}=30-40,1=20-30$, at first white, yellowish when old. Stipe $5-6 \times 0.2-0.6 \mathrm{~cm}$, cylindrical, sometimes inflated at base, solid in lower part, then hollow, whitish or cream in apical part, gets dark yellow when touched, in lower $2 / 3$ part covered with fugacious, greenish- 

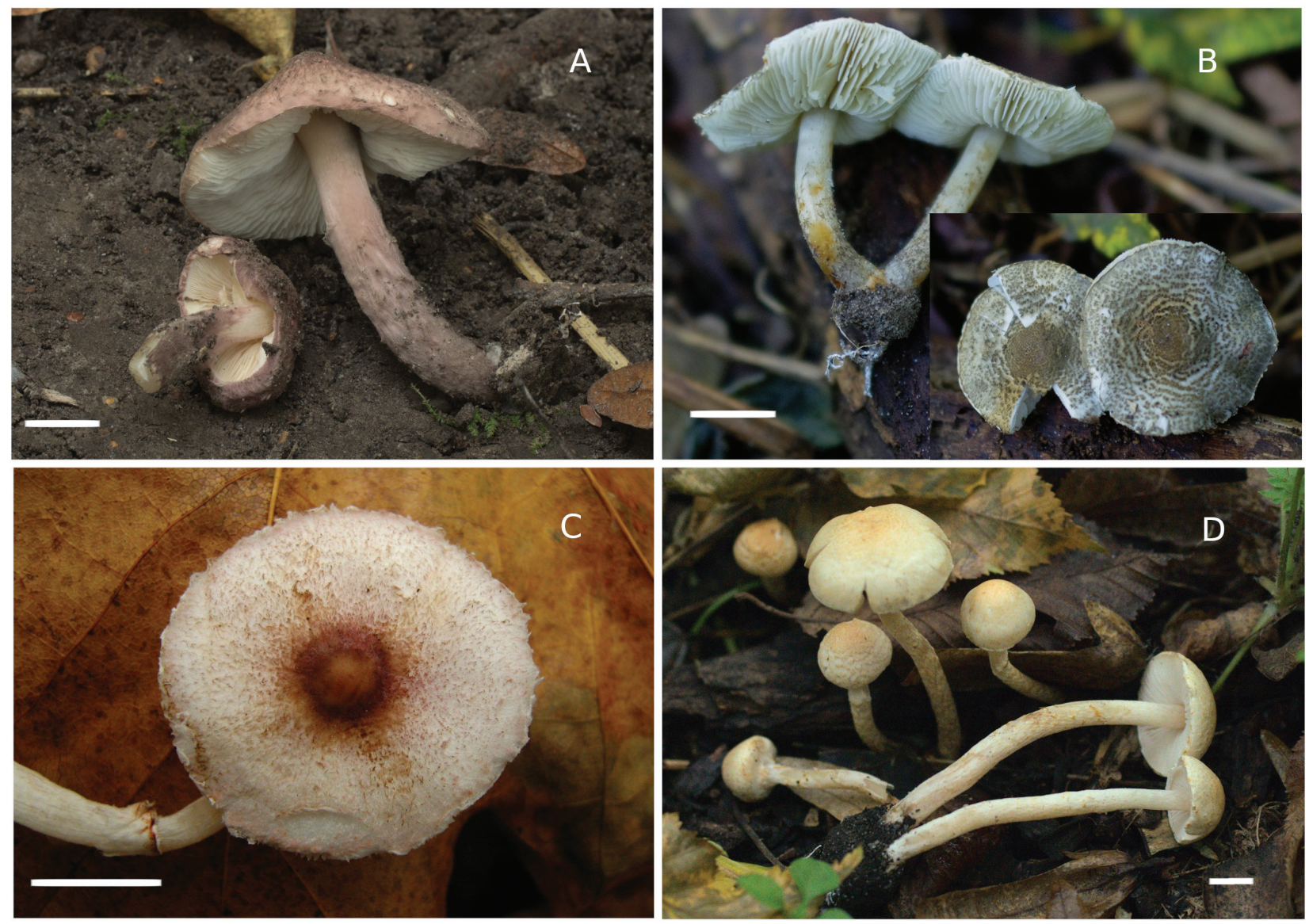

Fig 1. Fruit bodies of Lepiota species. A: L. fuscovinacea; B: L. griseovirens; C: L. roseolivida; D: L. subalba. Bars: $1 \mathrm{~cm}$

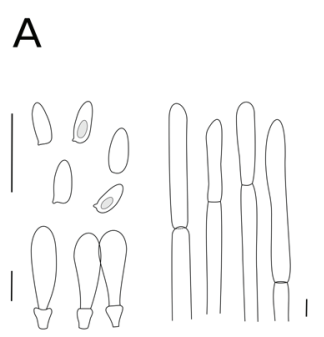

C

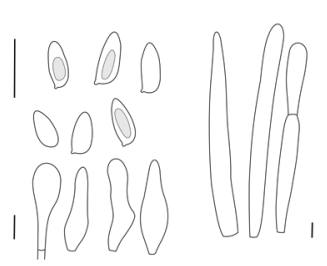

B

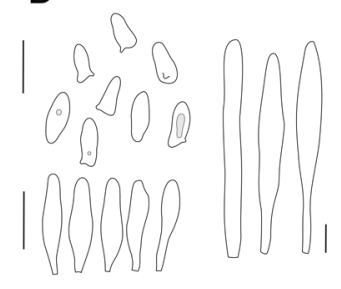

D

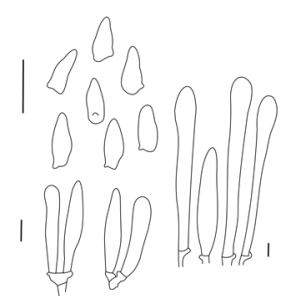

Fig. 2. Microscopic characters (spores, cheilocystidia, and pileipellis elements) of Lepiota species. A: L. fuscovinacea; B: L. griseovirens; C: L. roseolivida; D: L. subalba. Bars: $10 \mu \mathrm{m}$

gray to olive fibrillose velum remnants, which did not formed prominent annual zones in collected fruit bodies. Basidiospores (6.5-)7-8.5(-9.3) × 3-4.5 $\mu \mathrm{m}, \mathrm{Q}=23$ 2.97, subtriangular in side view, usually with suprahilar depression, ellipsoid to fusiform in front view, hyaline, smooth, dextrinoid, thick-walled. Basidia 17-20 × 5.5$7.0 \mu \mathrm{m}$, clavate, mostly four-spored, rarely two-spored. Pleurocystidia absent. Cheilocystidia (12.7-)15-20(-33) $\times 5.5-7.1 \mu \mathrm{m}$, clavate to narrowly utriform, sometimes fusiform, hyaline in KOH. Pileus covering a trichoderm, composed of elongate subcylindrical to subfusiform elements, 86-99 × 12.5-19.8 $\mu \mathrm{m}$, with light brown, yellowish parietal pigment. Clamp connections common.

Material examined. UKRAINE. Kharkiv Region, Zmiiv District, near Haydary village, $49.627082 \mathrm{~N}$, $36.3216094 \mathrm{E}$, on rich soil, edge of deciduous forest with Acer negundo, Robinia pseudoacacia, Salix sp., Sambucus nigra, Urtica dioica, 10 Oct. 2018, P. Havrysh \& O. Prylutskyi (CWU(MYC)8055). 
Habitat and distribution. Gregarious in small groups, terrestrial on sandy and loamy soils rich in humus, in deciduous and mixed woods and shrubs, as well as coastal dunes and ruderal places, rare in Europe. Reported from Austria, Belgium, Denmark, France, Germany, Greece, Italy, Russia, Spain, Sweden, Switzerland, the Netherlands, Ukraine, and the United Kingdom (Candusso, Lanzoni, 1990; Noordeloos et al., 2001; Lange, 2012; GBIF, 2021b).

Lepiota roseolivida Murrill, Mycologia 4(5): 234 (1912) - Figs 1,C, 2,C.

Lepiota marriageae D.A.Reid [as 'marriagei'], Fungorum Rariorum Icones Coloratae 1: 20 (1966) Lepiota roseilivida Murrill (Orthographic variant) Leucoagaricus marriageae (D.A.Reid) Bon [as 'marriagei'], Docums Mycol. 6(no. 24): 44 (1976) Leucoagaricus marriageae [as 'marriagei'] var. ammovirescens Bon, Docums Mycol. 22(no. 88): 31 (1993) - Leucoagaricus roseolividus (Murrill) E.Ludw. [as 'roseilividus'], Pilzkompendium (Eching) 3: 509 (2012).

Pileus $0.5-3.0 \mathrm{~cm}$ diam., slightly umbonate to applanate with low umbo or sometimes concave, dark ocher with violetish tinge around umbo with often lighter or paler shades at umbo apex, widely covered with lilac, brownish pink to violet tomentose elements which are small to tiny squamules laying on white background, with overhanging usually $\mathrm{V}$-shaped squamules at margin. Lamellae free, moderately crowded, $\mathrm{L}=40$ $45,1=15-20$, white to cream. Stipe 3.0-7.5 $\times 0.5-0.9$ $\mathrm{cm}$, cylindrical or subcylindrical, slightly wider in lower part, hollow, white, covered with white slightly tomentose elements over showing pale cream context, with distinct annulus containing brownish violet to ocher squamules that also occur in lower part and gradiently get thinner and paler to annulus. Basidiospores 7.38.1(-10.6) × 3.6-4.4 $\mu \mathrm{m}, \mathrm{Q}=1.78-1.97(-2.94)$, oblong, narrowly oblong to amygdaliform in side view, slightly narrowed to apex, oblong in front view, thick-walled, hyaline, smooth, dextrinoid, metachromatic. Basidia 15-26 $\times 6-9 \mu \mathrm{m}$ clavate, four-spored, rarely two-spored. Pleurocystidia absent. Cheilocystidia 33.3-37.2 × 9.8$11.8 \mu \mathrm{m}$, fusiform, narrowly fusiform, narrowly utriform, clavate, subcylindrical, hyaline in $\mathrm{KOH}$. Pileus covering a cutis, composed of elongate subcylindrical, subclavate elements sometimes narrowed to apex, (107-)148$230 \times 15.3-20.0 \mu \mathrm{m}$, with pale pinkish-lilac pigment. Clamp connections absent.

Material examined. UKRAINE. Kharkiv Region, Zmiiv District, near Koropiv Khutir village, Homilsha
Forests [Gomolshanski Lisy] National Nature Park, $49.60933517 \mathrm{~N}, 36.33022437 \mathrm{E}$, on litter, deciduous forest with Quercus robur, Tilia cordata, Fraxinus excelsior, Populus tremula, 25 Oct. 2009, O. Prylutskyi (CWU(MYC)7289).

Habitat and distribution. Solitary or in small groups, terrestrial, in deciduous forests, but also recorded along a path in a more ruderal setting; widespread in the USA, not common in Western Europe. Europe (UK, Italy, the Netherlands, Ukraine), North America (USA) (Noordeloos et al., 2001; Vellinga, 2006; GBIF, 2021d).

Described from the west coast of North America (Murrill, 1912), Lepiota roseolivida seems to be rarer in Europe than in North America. The Index Fungorum database follows Ludwig's concept, who placed this species in Leucoagaricus as L. roseolividus ['roseilividus'] in his Pilzkompendium (Ludwig, 2012). Since Ludwig provided no taxonomic evidence for that treatment, we keep original meaning and circumscription of this name, following Murrill (1912) and Vellinga (2006).

Lepiota subalba Kühner ex P.D.Orton, Trans. Br. Mycol. Soc. 43(2): 287 (1960) - Figs 1,D, 2,D.

Lepiota albosericea J.E.Lange, Fl. Agaric. Danic. 1: 32 (1935) - Lepiota subalba Kühner, Bull. trimest. Soc. mycol. Fr. 52(2): 233 (1936) - Lepiota subalba var. brunneoaurantia E.Ludw., Pilzkompendium (Eching) 3: 441 (2012).

Pileus $1.0-3.5 \mathrm{~cm}$ diam., convex, with age expanding, sometimes to umbonate with blunt apex, whitish, mostly cream, sometimes dirty-cream at disk, with mustard nontomentose squamules mostly crowded at center or often smooth, in young specimen with whitish veil at margin. Lamellae free, slightly ventricose, $\mathrm{L}=25-45,1=5-10$, white to cream-white. Stipe $2-7 \times 0.2-0.5 \mathrm{~cm}$, cylindrical or subcylindrical with inflated base, sometimes solid in lower part, then hollow, white, with gray-mustard, mustard to light brown squamules, sometimes in fuzzy concentric zones, covering all stipe under tomentose whitish annulus. Basidiospores $6.3-8.7 \times 2.8-3.7 \mu \mathrm{m}, \mathrm{Q}=$ (1.97-)2.22-2.82, subtriangular in side view, rarely with suprahilar depression, with protrusion at abaxial side, ellipsoid to subfusiform in front view, hyaline, smooth, metachromatic, thick-walled. Basidia 23.7-31.1 × 6.7$7.8 \mu \mathrm{m}$, clavate, usually four-spored, sometimes twospored. Pleurocystidia absent. Cheilocystidia (25.7-)37$55.2 \times 5.2-7.0 \mu \mathrm{m}$, narrowly clavate to fusiform, hyaline in $\mathrm{KOH}$. Pileus covering a trichoderm, composed of elongate subcylindrical to fusiform elements widen to apex, (59.5-)72-112 × 10.2-16 $\mu \mathrm{m}$. Clamp connections common. 
Table 3. Uncorrected p-distances between sequences of Lepiota specimens

\begin{tabular}{|c|c|c|c|c|c|c|}
\hline & CWU(MYC) 8416 & $\begin{array}{c}\text { L. subalba } \\
\text { UDB015447 } \\
118281\end{array}$ & $\begin{array}{c}\text { L. subalba } \\
\text { NOBAS2394-16 | } \\
\text { UDB036474 }\end{array}$ & $\begin{array}{c}\text { L. subalba } \\
\text { NOBAS1639-15 } \\
\text { |UDB036113 }\end{array}$ & $\begin{array}{l}\text { L. subalba } \\
\text { AY176489.1 }\end{array}$ & $\begin{array}{l}\text { L. ignicolor } \\
\text { AY176472.1 }\end{array}$ \\
\hline \multicolumn{7}{|l|}{ CWU(MYC) 8416} \\
\hline L. subalba UDB015447| 118281 & 0.0000 & & & & & \\
\hline L. subalba NOBAS2394-16 | UDB036474 & 0.0000 & 0.0000 & & & & \\
\hline L. subalba NOBAS1639-15 |UDB036113 & 0.0000 & 0.0000 & 0.0000 & & & \\
\hline L. subalba AY176489.1 & 0.0262 & 0.0262 & 0.0262 & 0.0262 & & \\
\hline L. ignicolor AY176472.1 & 0.0323 & 0.0323 & 0.0323 & 0.0323 & 0.0385 & \\
\hline
\end{tabular}

Material examined. UKRAINE. Kyiv city, Vystavkovyi Tsentr [Exhibition Center] park, 50.368372 N, 30.480649 E, on rich soil, deciduous forest with Carpinus betulus, 18 Oct. 2020, O. Prylutskyi (CWU(MYC)8416). iNaturalist observation - 62999172 (https://www.inaturalist.org/observations/62999172); GenBank accession number - OK041522 (https://www. ncbi.nlm.nih.gov/nuccore/OK041522).

Habitat and distribution. Solitary to gregarious in small groups, terrestrial on sandy to loamy soils rich in humus, in deciduous woods and shrubs, rarely in coniferous forests; rare, but locally occasional in Europe. Belgium, Estonia, Finland, France, Georgia, Germany, the Netherlands, Norway, Russia, Sweden, Switzerland, Ukraine, United Kingdom (Candusso, Lanzoni, 1990; Noordeloos et al., 2001; Lange, 2012; GBIF, 2021c).

Lepiota subalba was reported in Ukraine several times since 1954. According to the Fungi of Ukraine database (Andrianova et al., 2006), the KW Herbarium contains two deposited specimens identified as L. subalba, KW-M35462 and KW-M40649, both from Kherson Region, South Ukraine. Zerova mentioned this species name in 1959 and 1979 (Zerova, 1959; Zerova et al., 1979). However, Wasser in the volume of the Flora Fungorum RSS Ucrainicae on the family Agaricaceae (Wasser, 1980) did not use this name or any of its known synonyms. The last time $L$. subalba was mentioned in the Fungi of Reserves and National Nature Parks of the Leftbank Ukraine from the "Prydintsivska Zaplava" part of Luhansk Nature Reserve (Dudka et al., 2009).

Lepiota subalba demonstrates a wide variation in its morphology and might be confused with similar species from Lepiota sect. Stenosporae (Vellinga, 2003; Liang, 2016). To check and confirm our identification, we obtained the ITS sequence of our specimen, the trimmed region of which comprised 663 base pairs. Search in open databases resulted in five most similar sequences (Table 3).
Uncorrected p-distances were equal to zero in case of four sequences identified as L. subalba from Norway and Estonia, but has $2.6 \%$ difference in case of voucher specimen of that species from the Netherlands, while the sequence of a sister species, L. ignicolor, has slightly greater differentiation from both (3.2-3.9\%).

Both species share spurred spores and equally short pileus covering elements (trichoderm) and belong to the section Stenosporae in the traditional morphological classification (Bon, 1993). Molecular evidence suggests that both taxa belong to the wider clade, which includes also a very variable species $L$. castanea, with long pileus covering elements (Vellinga, 2003).

Despite high similarity in nrITS and LSU regions, Lepiota subalba and L. ignicolor significantly differ in their macromorphology. Lepiota subalba is characterized by its convex to bell-shaped, pale yellowish to pale ochraceous or creamy cap which is hardly cracked into squamules. Lepiota ignicolor, in contrast, possesses brightly ochraceous, brick or even warm orange-brown squamules, alongside with slenderer fruit bodies (Bon, 1993; Lange, 2012). Our specimen lies somewhere in between, approaching more closely $L$. subalba, with light brown, if not mustard squamules on its pileus and stem. Microscopic features, as far as we detected them, hardly helped in distinguishing between the two species.

Due to lack of material, L. subalba is treated as an obscure species. A thorough examination of this group is needed, using a wide range of samples from all over the Northern Hemisphere; the morphological variability and molecular data deserve equal attention (Vellinga, personal communication).

\section{Acknowledgments}

The authors are grateful to Dr. Else Vellinga for consultation on identification of some specimens. We are greatly indebted to Yulia Leshchenko and Dr. 
Iryna Yatsiuk for DNA extraction and further help with obtaining the ITS sequence, as well as two anonymous reviewers for their comments and corrections.

\section{References}

Abarenkov K., Tedersoo L., Nilsson R.H., Vellak K., Saar I., Veldre V., Parmasto E., Prous M., Aan A., Ots M., Kurina O., Ostonen I., Jõgeva J., Halapuu S., Põldmaa K., Toots M., Truu J., Larsson K.-H., Kõljalg U. 2010. PlutoF - a web based workbench for ecological and taxonomic research, with an online implementation for fungal ITS sequences. Evolutionary Bioinformatics, 6: EBO.S6271. https://doi.org/10.4137/EBO.S6271

Andrianova T.V., Dudka I.O., Hayova V.P., Heluta V.P., Isikov V.P., Kondratiuk S.Ya., Krivomaz T.I., Kuzub V.V., Minter D.W., Minter T.J., Prydiuk M.P., Tykhonenko Yu.Ya. 2006. Fungi of Ukraine. Online database. Available at: http://www.cybertruffle.org.uk/ukrafung/eng/index.htm (Accessed 13 September 2021).

Benson D.A., Cavanaugh M., Clark K., Karsch-Mizrachi I., Lipman D.J., Ostell J., Sayers E.W. 2013. GenBank. Nucleic Acids Research, 41(D1): D36-D42. https://doi. org/10.1093/nar/gks1195

Bon M. 1993. Flore mycologique d'Europe, 3. Les Lépiotes. Lepiotaceae Roze. Doc. Mycol. Mémoire hors série no. 3. L'Association d' Ecologie et de Mycologie, Lille, 153 pp.

Candusso M., Lanzoni G. 1990. Lepiota s. 1., vol. 4. Saronno: Libreriaeditrice Giovanna Biella, 760 pp.

Crous P.W., Gams W., Stalpers J.A., Robert V., Stegehuis G. 2004. MycoBank: An online initiative to launch mycology into the $21^{\text {st }}$ century. Studies in Mycology, 50(1): 19-22.

Dudka I.O., Heluta V.P., Andrianova T.V., Hayova V.P., Tykhonenko Yu.Ya., Prydiuk M.P., Golubtsova Yu.I., Kryvomaz T.I., Dzhagan V.V., Leontiev D.V., Akulov O.Yu., Syvokon O.V. 2009. Fungi of Nature Reserves and National Nature Parks of the Left-Bank Ukraine. Kyiv: Aristey, vol. 2, 428 pp. [Дудка I.О., Гелюта В.П., Андріанова Т.В., Гайова В.П., Тихоненко Ю.Я., Придюк М.П., Голубцова Ю.І., Кривомаз Т.І., Джаган В.В., Леонтьєв Д.В., Акулов О.Ю., Сивоконь О.В. 2009. Гриби заповідників та національних природних парків Лівобережної України. Київ: Арістей, т. 2, 428 с.].

Dudka I.O., Heluta V.P., Prydiuk M.P., Tykhonenko Yu.Ya., Akulov O.Yu., Hayova V.P., Zykova M.O., Andrianova T.V., Dzhagan V.V., Scherbakova Yu.V. 2019. Fungi of Reserves and National Nature Parks of the Ukrainian Carpathians. Ed. V.P. Heluta. Kyiv: Naukova Dumka, 215 pp. [Дудка I.О., Гелюта В.П., Придюк М.П., Тихоненко Ю.Я., Акулов О.Ю., Гайова В.П., Зикова М.О., Андріанова Т.В., Джаган В.В., Щербакова, Ю. В. 2019. Гриби заповідників $i$ начіональних природних парків Украӥнських Карпат. За ред. В.П. Гелюти. Київ: Наукова думка, 215 с.].
Dudka I.O., Heluta V.P., Tykhonenko Yu.Ya., Andrianova T.V., Hayova V.P., Prydiuk M.P., Dzhagan V.V., Isikov V.P 2004. Fungi of natural zones of Crimea. Kyiv: Phytosociocenter, 452 pp. [Дудка І.О., Гелюта В.П., Тихоненко Ю.Я., Андріанова Т.В., Гайова В.П., Придюк М.П., Джаган В.В., Ісіков В.П. 2004. Гриби природних зон Криму. Фітосоціоцентр, 452 с.].

Havrysh P., Zdvizova A., Prylutskyi O. 2018. First find of Lepiota griseovirens Maire from Homilsha Forests National Park (Kharkiv Forest-steppe, Ukraine). In: Proceedings of XIII Conference of young researchers "Biology: from a molecule up to the Biosphere" (28-30 November 2018, Kharkiv, Ukraine). Kharkiv, pp. 175-176.

Johnson J. 1999. Phylogenetic relationships within Lepiota sensu lato based on morphological and molecular data. Mycologia, 91(3): 443-458. https://doi. org $/ 10.2307 / 3761345$

Kirk P.M., Cannon P.F., Minter D.W., Stalpers J.A. (eds.). 2008. Ainsworth \& Bisby's Dictionary of the Fungi. $10^{\text {th }}$ ed. CABI. 771 pp.

Kozłowska M., Mułenko W., Anusiewicz M., Mamczarz M. 2019. An annotated catalogue of the fungal biota of the Roztocze Upland. Richness, diversity and distribution. Lublin: Polish Botanical Society, $452 \mathrm{pp}$.

Kumar S., Stecher G., Li M., Knyaz C., Tamura K. 2018. MEGA X: Molecular Evolutionary Genetics Analysis across Computing Platforms. Molecular Biology and Evolution, 35(6): 1547-1549. https://doi.org/10.1093/ molbev/msy096

Lange C. 2012. Lepiota. In: Funga Nordica: Agaricoid, boletoid, clavarioid, cyphelloid and gastroid genera. Eds. H. Knudsen, J. Vesterholt. Copenhagen: Nordsvamp, pp. $627-637$.

GBIF Secretariat. 2021a. GBIF Backbone Taxonomy. Checklist dataset. Lepiota fuscovinacea. Available at: https://doi. org/10.15468/dl.rggvpd (Accessed 28 September 2021).

GBIF Secretariat. 2021b. GBIF Backbone Taxonomy. Checklist dataset. Lepiota griseovirens. Available at: https://doi. org/10.15468/d1.9ne6nh (Accessed 05 October 2021).

GBIF Secretariat. 2021c. GBIF Backbone Taxonomy. Checklist dataset. Lepiota subalba. Available at: https://doi. org/10.15468/dl.jgbzr8 (Accessed 05 October 2021).

GBIF Secretariat. 2021d. GBIF Backbone Taxonomy. Checklist dataset. Leucoagaricus marriagei. Available at: https:// doi.org/10.15468/dl.gev4ph (Accessed 05 October 2021).

Liang J.F. 2016. Taxonomy and phylogeny in Lepiota sect. Stenosporae from China. Mycologia, 108(1): 56-69. https://doi.org/10.3852/14-192

Ludwig E. 2012. Pilzkompendium, Band 3. Berlin: FungiconVerlag, 881 pp.

Makarenko Ya.M. 2020. Fungi of the orders Agaricales, Boletales and Russulales in the Psel River basin (within the Left-Bank Forest-Steppe). PhD Thesis. M.G. Kholodny Institute of Botany, National Academy of Science of Ukraine, Kyiv, 262 pp. (manuscript). [Макаренко Я.М. 2020. Гриби порядків Agaricales, Boletales ma Russulales басейну річки Псел (у межах Лівобережного Лicocmeny). Дис.... канд.біол. наук. Інститут ботаніки ім. М.Г. Холодного НАН України, Київ, 262 с. (рукопис)]. 
Malaniuk V.B. 2020. Agaricoid and boletoid fungi of Halych National Nature Park. Vasyl Stefanyk Precarpathian National University, M.G. Kholodny Institute of Botany, National Academy of Science of Ukraine. Kyiv, 338 pp. (manuscript). [Маланюк В.Б. 2020. Агарикоїдні та болетоїдні гриби Галицького національного природного парку. Дис.... канд. біол. наук. Прикарпатський національний університет імені Василя Стефаника, Інститут ботаніки ім. М.Г. Холодного НАН України. Київ, 338 с. (рукопис)].

Murrill W.A. 1912. The Agaricaceae of the Pacific Coast II. Mycologia, 4: 231-262.

Nilsson R.H., Larsson K.-H., Taylor A.F.S., Bengtsson-Palme J., Jeppesen T.S., Schigel D., Kennedy P., Picard K., Glöckner F.O., Tedersoo L. 2019. The UNITE database for molecular identification of fungi: Handling dark taxa and parallel taxonomic classifications. Nucleic Acids Research, 47(D1): D259-D264. https://doi.org/10.1093/nar/gky1022

Noordeloos M.E., Kuyper T.W., Vellinga E.C. 2001. Flora agaricina Neerlandica: Critical monographs on families of agarics and boleti occurring in the Netherlands, vol. 5. Abington: A.A. Balkema Publishers, 169 pp.

Prylutskyi O.V. 2018. Agaricoid fungi of the Kharkiv ForestSteppe. PhD Thesis. M.G. Kholodny Institute of Botany National Academy of Sciences of Ukraine. Kyiv, 256 pp. (manuscript). [Прилуцький О.В. 2018. Агарикоїдні гриби Харківського Лісостепу. Дис.... канд.біол. наук. Інститут ботаніки ім. М.Г. Холодного НАН України. Київ, 256 с. (рукопис)].

Prylutskyi O.V., Akulov O.Y., Leontyev D.V., Ordynets A.V., Yatsiuk I.I., Usichenko A.S., Savchenko A.O. 2017. Fungi and fungus-like organisms of Homilsha Forests National Park, Ukraine. Mycotaxon, 132(3): 705-705(1). https:// doi.org/10.5248/132.705

Sarkina I.S. 2013. Fungi familiar and unfamiliar. Identification guide to Crimean fungi. $2^{\text {nd }}$ ed. Simferopol: BiznesInform. 440 pp. [Саркина И.С. 2013. Грибы знакомые и незнакомые. Справочник-определитель грибов Крыма. 2-е изд. Симферополь: Бизнес-Информ. 440 с.].

Vellinga E.C. 2003. Phylogeny of Lepiota (Agaricaceae) Evidence from nrITS and nrLSU sequences. Mycological Progress, 2(4): 305-322.
Vellinga E.C. 2004. Ecology and distribution of Lepiotaceous fungi (Agaricaceae) - a review. Nova Hedwigia, 78(3-4): 273-299.

Vellinga E.C. 2006. Lepiotaceous fungi in California, U.S.A. - 3. Pink and lilac species in Leucoagaricus sect. Piloselli. Mycotaxon, 99: 213-224.

Vellinga E.C. 2009. Nomenclatural Overview of Lepiotaceous Fungi (Agaricaceae). Version 4.7. Available at: https://www.yumpu.com/it/document/read/5395804/ nomenclatural-overview-of-lepiotaceous-fungiagaricaceae- (Accessed 23 September 2021).

Vellinga E.C., Sysouphanthong P., Hyde K.D. 2011. The family Agaricaceae: Phylogenies and two new whitespored genera. Mycologia, 103(3): 494-509. https://doi. org/10.3852/10-204

Wasser S.P. 1980. Flora fungorum RSS Ucrainicae: Basidiomycetes, Agaricaceae Cohn. Kiev: Naukova Dumka, 328 pp. [Вассер С.П. 1980. Флора грибов Украины: Агариковые грибы. Киев: Наукова думка, 328 c.].

Wasser S.P., Soldatova I.M. 1977. Higher Basidiomycetes of the Steppe zone of Ukraine. Kyiv: Naukova Dumka, 355 pp. [Вассер С.П., Солдатова И.М. 1977. Высшие базидиомицеты степной зоны Украины. Киев: Наукова думка, 355 с.].

Zerova M.Ya. 1959. New and little-known Agaricales from the Ukrainian SSR. Ukrainian Botanical Journal, 16(6): 75-82. [Зерова М.Я. 1959. Нові та маловідомі види агарикових грибів в Українській РСР. Украӥнський ботанічний журнал, 16(6): 75-82].

Zerova M.Ya., Sosin P.Ye., Rozhenko H.L. 1979. Handbook of Fungi of Ukraine, vol. 5. Basidiomycetes, book 2. Boletales, Strobilomycetales, Tricholomatales, Entolomatales, Russulales, Agaricales, Gasteromycetes. Kyiv: Naukova Dumka, 565 pp. [Зерова М.Я. Сосін П.С., Роженко Г.Л. 1979. Визначник грибів Украӥни, т. 5. Базидіоміцети, книга 2. Болетальні, стробіломіцетальні, трихоломатальні, ентоломатальні, русулальні, агарикальні, гастероміцети. Київ: Наукова думка, 565 с.].

Recommended for publication by V.P. Hayova

Прилуцький О., Зіненко О., Гавриш П. 2021. Перші знахідки трьох видів Lepiota (Agaricales, Basidiomycota) в Україні і нотатки про маловідомий вид Lepiota subalba. Украӥнський ботанічний журнал, 78(6): 373-380 [In English].

Харківський національний університет імені В.Н. Каразіна, м. Свободи 4, Харків 61022, Україна: О. Прилуцький, О. Зіненко, П. Гавриш. Музей природи Харківського національного університету імені В.Н. Каразіна, вул. Тринклера 8, Харків 61058, Україна: О. Зиненко.

Резюме. Наведено відомості про знахідки на території України чотирьох видів роду Lepiota (Agaricales, Basidiomycota). Три види - L. fuscovinacea, L. griseovirens та L. roseolivida - наводяться вперше для України. Повідомлення про маловідомий вид L. subalba, який раніше відмічався в Україні, підтверджено $з$ використанням молекулярно-генетичних методів ідентифікації. Для кожного виду подано оригінальні описи, що супроводжуються ілюстраціями, даними про загальне поширення, оселищні уподобання та посиланнями на колекційні зразки і відкриті бази даних. Наведено оригінальну нуклеотидну послідовність ITS регіону рибосомальної ДНК, отриману із зібраного нами зразка L. subalba.

Ключові слова: ДНК-штрихкодування, грибне різноманіття, ІТС, лепіотоїдні гриби, нові знахідки, Україна 